\title{
Protein nutrition in late pregnancy, maternal protein reserves and lactation performance in dairy cows
}

\author{
Alan W. Bell*, Winfield S. Burhans and Thomas R. Overton \\ Department of Animal Science, Cornell University, Ithaca, NY 14853-4801, USA
}

\begin{abstract}
Empirical evidence suggests that prolonged underfeeding of protein to late-pregnant dry cows can have modest negative carry-over effects on milk volume and/or protein yield during early lactation, and may also cause increased incidence of metabolic diseases associated with fatty liver. However, assessment of requirements is hampered by lack of information on relationships between dietary intake of crude protein $(\mathrm{N} \times 6.25)$ and metabolizable protein supply during late pregnancy, and by incomplete understanding of the quantitative metabolism of amino acids in maternal and conceptus tissues. Inability of the postparturient cow to consume sufficient protein to meet mammary and extra-mammary amino acid requirements, including a significant demand for hepatic gluconeogenesis, necessitates a substantial, albeit transient, mobilization of tissue protein during the first 2 weeks of lactation. Ultimately, much of this mobilized protein appears to be derived from peripheral tissues, especially skeletal muscle and, to a lesser extent, skin, through suppression of tissue protein synthesis, and possibly increased proteolysis. In the shorter term, soon after calving, it is likely that amino acids required for hepatic glucose synthesis are diverted from high rates of synthesis of splanchnic tissue and export proteins, including serum albumin. The prevailing endocrine milieu of the periparturient cow, including major reductions in plasma levels of insulin and insulin-like growth factor-I, together with insulin resistance in peripheral tissues, must permissively facilitate, if not actively promote, net mobilization of amino acids from these tissues.
\end{abstract}

Periparturient dairy cow: Protein requirements: Tissue protein mobilization

The notion that protein nutrition of dry dairy cows during late pregnancy influences postpartum health and lactation performance is pervasive, but studies designed to test this hypothesis have yielded conflicting results. Part of the problem is due to uncertainty about the relationship between dietary protein intake and metabolizable protein supply in pregnant dry cows. The metabolizable protein requirement of the pregnant dry cow is also not well defined, because of imprecisions in the factorial estimation of amino acid requirements for maintenance, conceptus growth and mammogenesis. As discussed later (p. 121), present estimates for maintenance and conceptus growth, in particular, suffer from a lack of quantitative information on the metabolic fates and efficiencies of utilization of absorbed amino acids. However, an additional factor, which is seldom formally considered in the factorial approach, is the possible need to supply amino acids for deposition in or export from maternal non-uterine tissues, including the splanchnic organs, skeletal muscle and other structural tissues, which might constitute a labile protein reserve that is drawn on during early lactation.

The present paper will briefly summarize the literature on lactation performance responses to protein feeding during the dry period, before discussing the bases for factorial estimation of the changing amino acid requirements during the periparturient period. Questions about maternal protein reserves will then be addressed, including their anatomical location, functional significance, and nutritional and endocrine regulation.

\section{Responses during early lactation to protein feeding of dry cows \\ Milk yield and composition}

As summarized in Table 1, effects of level of dietary protein fed to late-pregnant dry cows on postpartum lactation performance have been variable, with a majority of studies 
Table 1. Summary of studies investigating lactation responses to prepartum supplementation of dietary protein

\begin{tabular}{|c|c|c|c|}
\hline \multirow[b]{2}{*}{ Source } & \multirow[b]{2}{*}{ Prepartum dietary crude protein $(\mathrm{N} \times 6.25 ; \mathrm{CP} ; \mathrm{g} / \mathrm{kg} \mathrm{DM})$} & \multicolumn{2}{|c|}{ Milk response } \\
\hline & & Yield (kg) & $\operatorname{Protein}(\mathrm{g} / \mathrm{kg})$ \\
\hline Chew et al. (1984) & 96 v. 120 & $\uparrow$ & $\uparrow$ \\
\hline Hook et al. (1989) & 99 v. 130 & $\uparrow$ & - \\
\hline Van Saun et al. (1993) & 124 v. 153 & - & $\uparrow$ \\
\hline Crawley \& Kilmer (1995) & $\begin{array}{c}120 \text { v. } 150 \\
\text { 150; low v. high RUP }\end{array}$ & $\downarrow$ & - \\
\hline Van Saun \& Sniffen (1995) & NR; low v. high RUP & - & - \\
\hline Moorby et al. (1996) & $\begin{array}{l}\text { NR; low v. high RUP } \\
\text { NR; low v. high RUP }\end{array}$ & $\begin{array}{l}\uparrow \\
-\end{array}$ & $\overline{-}$ \\
\hline Greenfield et al. (1998) & $\begin{array}{c}120 \text { v. } 160 \\
160 ; 260 \text { v. } 330 \text { g RUP/kg CP }\end{array}$ & $\downarrow$ & - \\
\hline Huyler et al. (1997) & $\begin{array}{l}117 \text { v. } 156 \\
117 \text { v. } 205\end{array}$ & $\begin{array}{l}\uparrow \\
\uparrow\end{array}$ & - \\
\hline Carson et al. (1998) & 139 v. 156 & - & - \\
\hline Putnam et al. (1999) & 130 v. 178 & - & - \\
\hline
\end{tabular}

NR, not reported; RUP, rumen-undegradable protein; $\uparrow$, increase; $\downarrow$, decrease; -, no change.

finding little response in milk yield, protein concentration or protein yield. Closer examination of studies in which significant positive responses were observed reveals several associated factors that may influence the response, including relative level of prepartum dietary protein, duration of supplementation and level of protein in the lactation diet.

In four of the six comparisons in which a positive milk yield response to prepartum supplementation of dietary protein was observed, the negative control diet contained less than $120 \mathrm{~g}$ crude protein $(\mathrm{N} \times 6.25 ; \mathrm{CP}) / \mathrm{kg} \mathrm{DM}$; Chew et al. 1984; Hook et al. 1989; Huyler et al. 1997). This factor is also true of a study on dairy goats in which milk yield during early lactation responded positively to an increase in prepartum dietary protein (Sahlu et al. 1995). Another two positive responses were obtained where the control diet contained more than $120 \mathrm{~g} \mathrm{CP} / \mathrm{kg}$ DM (Moorby et al. 1996; Greenfield et al. 1998). However, in both these studies the basal diet appeared to be very low in undegradable protein content. It may be inferred that this factor negatively influenced metabolizable protein yield and allowed greater opportunity for a response to supplemental undegradable protein. Another characteristic of most studies in which positive responses were observed was their longer duration relative to studies in which neutral or negative responses were obtained. Four of six positive responses occurred when treatments were applied for at least 6 weeks. In one exception (Van Saun et al. 1993) primigravid cows were fed on diets containing either 124 or $156 \mathrm{~g} \mathrm{CP} / \mathrm{kg} \mathrm{DM}$ for only 3 weeks prepartum, and treated cows showed a significant increase in milk protein concentration but not milk yield during the first 6 weeks of lactation. In the other exception cows were fed on diets containing $160 \mathrm{~g} \mathrm{CP} / \mathrm{kg}$ $\mathrm{DM}$, with low $v$. high levels of rumen-undegradable protein, for 4 weeks prepartum (Greenfield et al. 1998). In contrast, in seven of eight treatment comparisons that did not show a positive response, treatments were imposed for periods of less than 6 weeks.

It may also be noteworthy that increased prepartum protein produced the greatest percentage increases in milk yield when lactation diets were reported or estimated to be less than or equal to $160 \mathrm{~g} \mathrm{CP} / \mathrm{kg} \mathrm{DM}$ in cows (Chew et al. 1984) and goats (Sahlu et al. 1995). In rats and pigs protein deficiency during pregnancy has a negative effect on lactation performance only when the lactation diet is also insufficient in protein (Mahan \& Mangan, 1975; Greenhalgh et al. 1977; Shields et al. 1985; Pine et al. 1994). Thus, in modern feeding regimens the relatively-high-protein diets fed to cows during early lactation may mask the impact of moderate protein insufficiency of prepartum diets.

Two preliminary reports of negative effects of prepartum protein supplementation on subsequent milk yield (Crawley \& Kilmer, 1995; Greenfield et al. 1998) are difficult to interpret without more detail. However, considering an earlier report that prepartum feeding of a diet containing $150 v$ v. $85 \mathrm{~g} \mathrm{CP} / \mathrm{kg} \mathrm{DM}$ was associated with markedly increased incidence of periparturient health disorders (Julien et al. 1976) and the apparent lack of productive benefit from high $v$. moderate protein levels in prepartum diets, there is little incentive to excessively increase the protein concentration of prepartum diets.

The expression of protein requirements in terms of dietary $\mathrm{CP}$ is a major flaw in the earlier analysis of postpartum responses to protein feeding during late pregnancy. In pregnant dry cows, as in lactating cows, the relationship between CP intake and metabolizable protein supply is quite variable and highly dependent on the quality and level of dietary protein, as well as the availability of fermentable energy for rumen microbial protein synthesis. Examples are shown in Table 2, based on studies in which different levels and forms of dietary protein (Putnam \& Varga, 1998) or energy (Minor et al. 1998) were fed to dry cows, and metabolizable protein supply was estimated using the Cornell Net Carbohydrate Protein system (Sniffen et al. 1992). Although all modern feeding systems for ruminants are based on dynamic predictions of amino acid availability, the tendency to express dry cow requirements in terms of dietary CP is pervasive, at least in North America, and quite misleading. The additional problem of factorial estimation 
Table 2. Examples of variations in the metabolizable protein yield of dry-cow diets related to protein content and energy source

\begin{tabular}{|c|c|c|c|c|c|}
\hline \multirow{3}{*}{$\begin{array}{l}\text { Source ... } \\
\text { Variable }\end{array}$} & \multicolumn{3}{|c|}{ Putnam \& Varga (1998) } & \multicolumn{2}{|c|}{ Minor et al. (1998) } \\
\hline & \multicolumn{3}{|c|}{ Dietary CP } & \multicolumn{2}{|c|}{ Dietary NFC } \\
\hline & Low & Medium & High & High & Medium \\
\hline DM intake $(\mathrm{kg} / \mathrm{d})$ & $11 \cdot 0$ & $11 \cdot 2$ & $11 \cdot 1$ & $13 \cdot 2$ & $10 \cdot 2$ \\
\hline NFC (g/kg DM) & 339 & 330 & 301 & 438 & 235 \\
\hline NDF (g/kg DM) & 417 & 436 & 430 & 295 & 489 \\
\hline $\mathrm{CP}(\mathrm{g} / \mathrm{kg} \mathrm{DM})$ & 106 & 127 & 145 & 132 & 144 \\
\hline CP intake $(g / d)$ & 1166 & 1422 & 1639 & 1690 & 1469 \\
\hline MP supply (g/d) & 971 & 1119 & 1186 & 1226 & 829 \\
\hline MP:CP & 0.83 & 0.79 & 0.72 & 0.73 & 0.56 \\
\hline
\end{tabular}

NFC, non-fibre carbohydrate; NDF, neutral-detergent fibre; $\mathrm{CP}$, crude protein $(\mathrm{N} \times 6 \cdot 25)$; MP, metabolizable protein estimated using Cornell Net Carbohydrate Protein system (Sniffen et al. 1992).

of metabolizable protein requirements during late pregnancy is discussed below.

\section{Liver metabolism and health}

It has been suggested that protein supplementation of pregnant dry cows may decrease the incidence of metabolic disease during early lactation, which may or may not be related to observed effects on lactation performance. For example, Van Saun \& Sniffen (1995) reported a significant reduction in postpartum incidence of ketosis in multiparous cows supplemented with rumen-undegradable protein during late pregnancy, although no effects on milk yield or composition were observed. Such an effect may be mediated through a reduction in the degree of hepatic lipid accumulation that appears to be central, if not causally related, to the aetiology of ketosis and several other metabolic diseases commonly seen in dairy cattle during early lactation (Grummer, 1993). This idea is consistent with the finding of Holtenius \& Hjort (1990) that dry cows fed on diets high in energy but low in protein suffered a major increase in the severity of fatty liver at parturition compared with cows fed on high-energy high-protein or low-energy low-protein diets. A similar response was induced by Hippen et al. (1999) who fed cows on a diet very high in energy but with only $120 \mathrm{~g} \mathrm{CP} / \mathrm{kg}$ for $30 \mathrm{~d}$ before calving. The hepatic supply of protein, or specific amino acids, may be limiting for synthesis of apolipoprotein B, and therefore hepatic lipid disposal via synthesis and secretion of VLDL. Several studies have suggested that hepatic synthesis of apolipoprotein B is impeded in cows with fatty liver (Mazur et al. 1992; Gruffat et al. 1996, 1997), and there is limited preliminary evidence that supplementation of cows with rumen-protected lysine and methionine may improve hepatic secretion of VLDL during early lactation (Durand et al. 1992). Later work by this group (Bauchart et al. 1998) has confirmed that supplementation of rumenprotected lysine and methionine can reduce liver triacylglycerol at 2 and 4 weeks postpartum, and plasma ketone levels at 2 weeks postpartum. This treatment also increased the hepatic concentration of apolipoprotein B100 at 4 weeks postpartum, consistent with the notion of improved capacity for VLDL synthesis and secretion.

\section{Changes in amino acid requirements during the periparturient period}

\section{Requirements during late pregnancy}

The factorial estimation of protein requirements for dairy cattle by the National Research Council (1989) accounts for maintenance protein requirements as the sum of endogenous urinary protein $\left(2.75 \mathrm{BW}^{0.5}\right.$, where $\mathrm{BW}$ is body weight), scurf protein $\left(0 \cdot 2 \mathrm{BW}^{0 \cdot 6}\right)$, and metabolic faecal protein $(0.09 \times$ indigestible $\mathrm{DM}$ excretion). Absorbed protein is assumed to be utilized with an efficiency of $67 \%$ for formation of endogenous urinary protein and scurf protein. The net protein required for conceptus growth is calculated as $1.136 \mathrm{BW}^{0.70}$ and absorbed protein is considered to be used for conceptus growth with an efficiency of $50 \%$. This information leads to an estimated metabolizable protein requirement of $742 \mathrm{~g} / \mathrm{d}$ for a mature dry cow weighing $650 \mathrm{~kg}$ and approximately 3 weeks before calving. This estimate has several uncertainties. First, the maintenance algorithm takes no account of possible effects of pregnancy on amino acid metabolism in maternal tissues other than the gravid uterus, but with the absence of hard evidence to the contrary, there is little option but to retain the present estimate. Second, while the estimate of net protein requirement for conceptus growth is not inconsistent with our direct measurements of protein accretion in the gravid uterus of mature Holstein cows during late pregnancy (Bell et al. 1995), the assumed efficiency of utilization of absorbed protein is probably an overestimate. Measurements of uterine uptake of amino acids in relation to protein accretion by the conceptus in sheep indicate that the efficiency term is no more than $40 \%$ (Chung et al. 1998), while sparser data on cattle suggest a value as low as $30 \%$ (Bell, 1995). Use of a factor of $33 \%$, as suggested by Bell et al. (1995), applied to the net requirement predicted by the National Research Council (1989) leads to a metabolizable protein requirement of about $320 \mathrm{~g} / \mathrm{d}$, compared with $212 \mathrm{~g} / \mathrm{d}$ estimated by the National Research Council (1989) approach. Finally, the estimate obtained by the National Research Council (1989) approach does not account for mammary growth during the last few weeks of pregnancy. This factor is probably trivial before 3 weeks prepartum, but could account for about $120 \mathrm{~g}$ metabolizable protein/d 
during the last 3 weeks of the dry period, based on measured values for mammary tissue growth in periparturient cows (Capuco et al. 1997) and mammary tissue protein concentration in late-pregnant ewes (McNeill et al. 1997), and an assumed efficiency of utilization of absorbed protein of $67 \%$. Thus, a more realistic estimate of metabolizable protein requirements of the late-pregnant dry cow is probably approximately $1000 \mathrm{~g} / \mathrm{d}$.

\section{Requirements during early lactation}

According to the National Research Council (1989), factorial estimation of metabolizable protein requirements for lactation involves separate estimation of requirements for maintenance, as described earlier, and for milk synthesis, based on milk protein yield (net requirement) and a value of $70 \%$ for the efficiency of utilization of absorbed protein. Measured values for milk yield $(30 \mathrm{~kg} / \mathrm{d})$ and milk protein concentration $(420 \mathrm{~g} / \mathrm{kg})$ in cows weighing $650 \mathrm{~kg}$ and tested at $4 \mathrm{~d}$ postpartum yield an estimated metabolizable protein requirement of $2170 \mathrm{~g} / \mathrm{d}$. An additional $120 \mathrm{~g} / \mathrm{d}$ for mammary growth probably should be included because this process continues into early lactation (Akers et al. 1981). Thus, the total requirement during the first week of lactation is at least $2300 \mathrm{~g} / \mathrm{d}$, which is $2 \cdot 3$ times that required before calving just a few days earlier. Once again, this conservative estimate does not account for the almost certain increase in maintenance requirements in lactating $v$. non-lactating animals.

\section{Impact of periparturient changes on protein balance}

We have used the conservative factorial approach described earlier, together with individually-measured values for metabolizable protein intake, to derive calculated protein balances for a group of eighty Holstein cows through the first $28 \mathrm{~d}$ of lactation (Fig. 1; Burhans \& Bell, 1998). Calculated protein balance decreased to a nadir of about $-600 \mathrm{~g} / \mathrm{d}$ at $7 \mathrm{~d}$ postpartum, then steadily increased for the next 3 weeks, with zero balance apparently achieved at

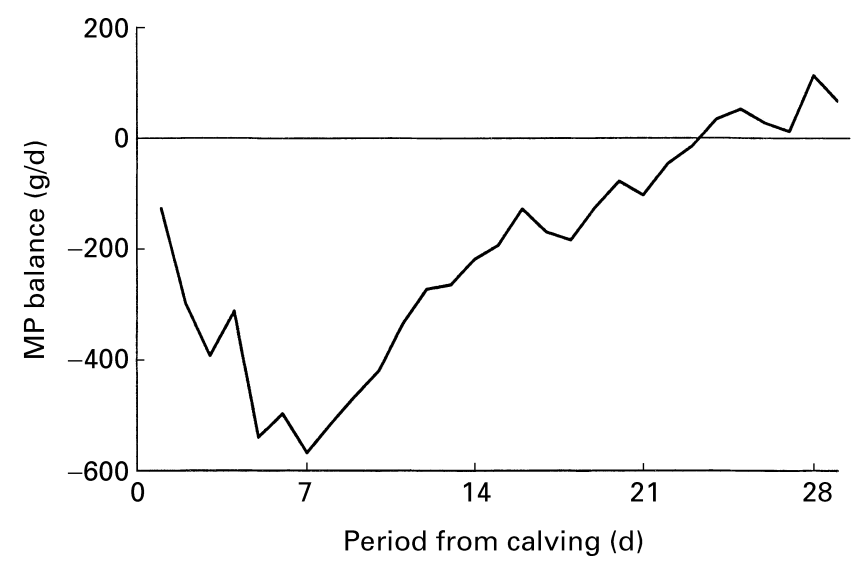

Fig. 1. Calculated metabolizable protein (MP) balance in postparturient cows $(n 80)$ fed on a ration containing $(/ \mathrm{kg}$ DM) $178 \mathrm{~g}$ crude protein (nitrogen $\times 6.25$ ) and $7.0 \mathrm{MJ}$ net energy for lactation. Individual values were calculated from daily individual measurements of crude protein intake and milk yield, and weekly measurements of milk composition. about $23 \mathrm{~d}$ postpartum. This estimate must be regarded as minimal, because it does not account for another potentially major avenue of amino acid utilization, hepatic gluconeogenesis.

Several lines of evidence point to an important, if transient, reliance on glucogenic amino acids to make up a shortfall in rumen propionate production, related to constrained voluntary DM intake during early lactation. Calculations based on generous predictions of availability of propionate, glycerol, and lactate for hepatic gluconeogenesis suggest a shortfall in glucose precursors of at least $500 \mathrm{~g} / \mathrm{d}$ in a cow producing $30 \mathrm{~kg}$ milk and consuming $15 \mathrm{~kg} \mathrm{DM} / \mathrm{d}$ of a high-quality ration during the first week of lactation (Bell, 1995). The estimated metabolizable protein supply under these conditions was $1650 \mathrm{~g} / \mathrm{d}$, which barely accounts for the requirement for milk protein synthesis. This factor leads to the unavoidable conclusion that simply to fulfil the cow's need to synthesize glucose, at least $500 \mathrm{~g}$ endogenous protein/d must be mobilized, in addition to that required for other maintenance purposes. Some of this additional requirement may be offset by reduced oxidation of glucose in peripheral tissues (Bennink et al. 1972), consistent with the characteristic insulin resistance in these tissues during early lactation in ruminants (Debras et al. 1989; Vernon et al. 1990). It is also evident that the liver's capacity for converting alanine, and probably other glucogenic amino acids, is up regulated in dairy cows soon after calving (Fig. 2; Overton et al. 1998). The regulatory mechanism is not known, but presumably involves perception of glucose demand, because similar up regulation can be elicited by treating wethers with phlorizin (Overton et al. 1999). Another piece of persuasive semi-quantitative evidence for the significant net conversion of tissue protein to glucose was provided by Wilson et al. (1988). These workers estimated the proportions of $\mathrm{C}$ in individual milk constituents derived from feed and body tissues in dairy cows, taking advantage of natural variations in ${ }^{13} \mathrm{C}:{ }^{12} \mathrm{C}$ present in $\mathrm{C}_{3^{-}}$and $\mathrm{C}_{4}$-pathway plant species. These estimates suggested that during early lactation as much as $34 \%$ of the casein and $24 \%$ of the lactose in milk could

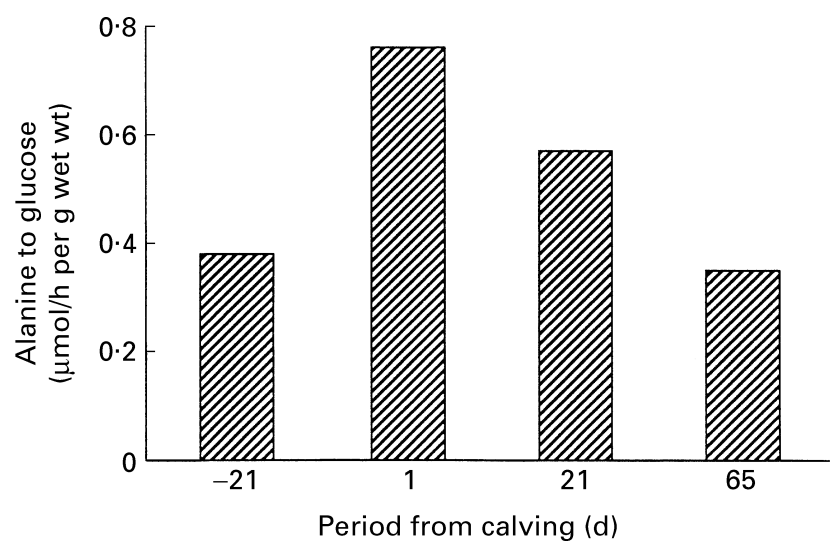

Fig. 2. Conversion of $\left[1-{ }^{14} \mathrm{C}\right]$ alanine to glucose in liver slices from dairy cows that were serially biopsied at various stages before and after parturition. Values are means for thirty-six cows (pooled SE 0.16). (From the data of Overton et al. 1998.) 
have been derived from body tissue protein, with cows of high genetic merit having greater values than less superior cows. These estimates should be discounted for likely influence of nutrient turnover, because smaller but significant values for the contributions of tissue protein to milk constituents were obtained in late lactation, when cows were close to zero energy and protein balance.

Thus, we believe that during the first $7-10 \mathrm{~d}$ of lactation, at least, high-yielding dairy cows may need to mobilize as much as $1000 \mathrm{~g}$ tissue protein/d to satisfy the mammary gland's demand for amino acids and glucose. Clearly, such a tissue loss could not be sustained for very long, and should diminish as the cow's voluntary consumption of a highprotein diet continues to increase. However, it raises several questions about the tissue source, mechanisms and regulation of endogenous protein mobilization that will be discussed now.

\section{Labile protein reserves in maternal tissues}

\section{Tissue source and mechanisms of protein mobilization}

Several serial slaughter studies have directly or indirectly investigated the net loss of protein from the empty body and specific tissues of dairy cows during different phases of the reproduction-lactation cycle (Belyea et al. 1978; Tyrrell \& Haaland, 1983; Gibb et al. 1992; Andrew et al. 1994). Most studies showed a modest loss of protein from carcass tissues during early lactation, but sampling intervals were generally too long to allow detection of transient responses, and in some cases tissue specificity was not reported. We have examined the partitioning of $\mathrm{CP}$ among maternal and conceptus tissues in ewes during the last month of pregnancy, and observed that even in animals fed to predicted requirements for metabolizable protein there was a moderate net loss of carcass protein over this period (Fig. 3; McNeill et al. 1997). In animals that were fed on a protein-insufficient but energy-sufficient diet the loss of carcass protein was exacerbated and the net increase in protein accretion in visceral and mammary tissues seen in control animals was attenuated (Fig. 3).

Data on tissue protein synthesis in goats during early lactation provide additional insight into carcass tissue specificity as well as possible mechanisms of protein mobilization (Baracos et al. 1991). Absolute values for protein synthesis in hindlimb tissues were reduced by $45 \%$ for skin, $14 \%$ for bone marrow and $29 \%$ for skeletal muscle in goats during the third week of lactation compared with dry goats. These reductions contributed $30,<1$ and $69 \%$ respectively to the total reduction in protein synthesis in hindlimb tissues during early lactation. Thus, it seems fairly clear that suppression of protein synthesis in skeletal muscle and skin could contribute to net mobilization of amino acids in the postparturient cow, consistent with observations of reduced muscle fibre diameter in early lactation (Reid et al. 1980). Augmentation of this response by increased myofibrillar protein degradation is suggested by the marked increase in urinary 3-methylhistidine:creatinine in parturient dairy cows (Overton et al. 1998), accompanied by a similar pattern of increase in plasma concentrations of 3-methylhistidine

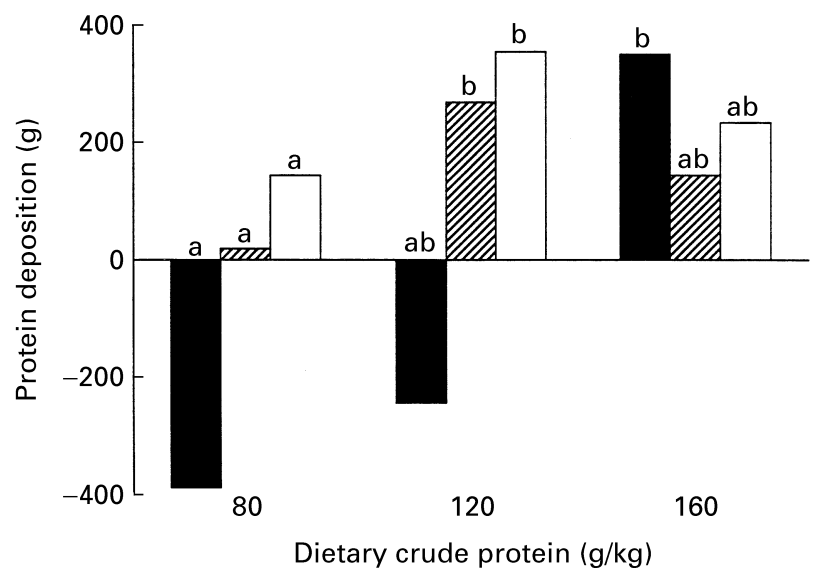

Fig. 3. Protein deposition between days 110 and 140 of pregnancy in maternal tissue components of ditocous ewes fed on diets containing different levels of dietary crude protein (nitrogen $\times 6 \cdot 25$ ). Values are means for eight ewes (pooled SE were $214 \mathrm{~g}$ for carcass $(\square), 84 \mathrm{~g}$ for organs (ma) and $44 \mathrm{~g}$ for mammary gland $\square$ ). ${ }^{\text {a,bWithin }}$ tissue components, means with different superscript letters were significantly different $(P<0 \cdot 05)$. (Adapted from the data of McNeill et al. 1997.)

(Burhans et al. 1997). This response may be partly influenced by uterine involution and myometrial protein degradation in the early postpartum period, but the magnitude and sustained pattern of response suggests a major additional source of muscle protein breakdown.

Reduced hypertrophy of visceral tissues in proteinrestricted ewes during late pregnancy (McNeill et al. 1997) suggests that modulation of the normal major increase in protein synthesis in liver (Bell, 1995), and presumably gut tissues, during early lactation may be an additional source for diversion of amino acids to catabolic fates. Such a response could be more immediate, albeit short-lived, than effects on carcass tissues because of the much greater rates of protein turnover in splanchnic $v$. muscle and skin. In addition to temporarily constraining tissue growth of the visceral organs, this response might also reduce the synthesis of export proteins, including apolipoprotein B, with consequences for hepatic lipid disposal. Reduction in hepatic synthesis of albumin and other quantitatively important serum proteins is suggested by moderate reductions in their circulating concentrations in periparturient cows (Rowlands et al. 1975).

\section{Nutritional and endocrine regulation of tissue protein mobilization}

It is not known whether the size of the so-called labile protein reserve at parturition has an influence on mobilization of amino acids during the early postpartum period. However, it is evident that $\mathrm{N}$ balance and tissue accumulation of protein is directly responsive to dietary protein intake in dairy cows (Putnam \& Varga, 1998) and ewes (McNeill et al. 1997) during late pregnancy. In ewes most of this additional protein was deposited in carcass tissues (Fig. 3). The degree to which postparturient mobilization of amino acids is responsive to nutrition during 
early lactation also requires study. Intuitively, a response to dietary protein would be expected. It seems reasonable that glucogenic supplementation of newly-calved cows should ameliorate the apparent increase in muscle protein degradation, indicated by plasma concentrations of 3-methylhistidine. However, this hypothesis was not confirmed in cows orally supplemented with $500 \mathrm{~g}$ propylene glycol/d, despite other indices of metabolic benefit (Burhans et al. 1997). It remains possible that net mobilization of endogenous protein is nonetheless modulated by glucogenic substrate supply, via changes in synthesis rather than degradation of labile protein reserves.

No studies have directly addressed the endocrine or local regulation of tissue protein mobilization in the postparturient cow, and so much of the following discussion is speculative. However, the likely pattern of reduced protein synthesis, and possibly increased proteolysis in hindlimb and other tissues, is consistent with observed changes in plasma concentrations of, and tissue responses to, key endocrine regulators of tissue protein metabolism, including insulin and insulin-like growth factor (IGF)-I (Fig. 4). Despite a marked and persistent increase in plasma growth hormone, the precipitous decline in plasma concentrations of IGF-I parallels that in insulin, beginning about 2 weeks before calving. Other workers have reported reduced plasma levels of IGF-binding protein-3 and increased levels of IGF-binding protein-2, concomitant with the reduction of circulating IGF-I (Simmons et al. 1994; Segoale et al. 1997). Associated with lactation-induced insulin resistance in peripheral tissues (Vernon et al. 1990), these endocrine changes must have at least a permissive regulatory influence in suppressing protein synthesis and enhancing proteolysis. The removal of the normal positive influence of growth hormone on plasma IGF-I and IGF-binding protein-3 is consistent with similar observations during later lactation in cows that were moderately or severely underfed (McGuire et al. 1995). The possibly separate influences of protein $v$. energy insufficiency in mediating this disconnection of the growth hormone-IGF axis have yet to be clarified. However, it is interesting to note a recent report that inadequate supply of total amino acids or simply methionine was able to totally suppress the stimulation by growth hormone of IGF-I synthesis in cultured ovine hepatocytes (Wheelhouse et al. 2000).

\section{Conclusions}

Understanding relationships between dietary protein intake, tissue protein reserves, and performance and health of dairy cows during early lactation will be greatly assisted if diets are described in terms of metabolizable (absorbed) protein rather than $\mathrm{CP}$ content. There is also a need to more precisely determine the efficiency of utilization of amino acids for conceptus growth during late pregnancy in dairy cows. Net protein requirements have been established but must be combined with measurements of net uterine uptake of amino acids to derive a reliable efficiency factor.

Indirect evidence for the importance of tissue protein mobilization during early lactation is compelling, but requires confirmation by more direct experimental approaches under well-defined nutritional conditions. There
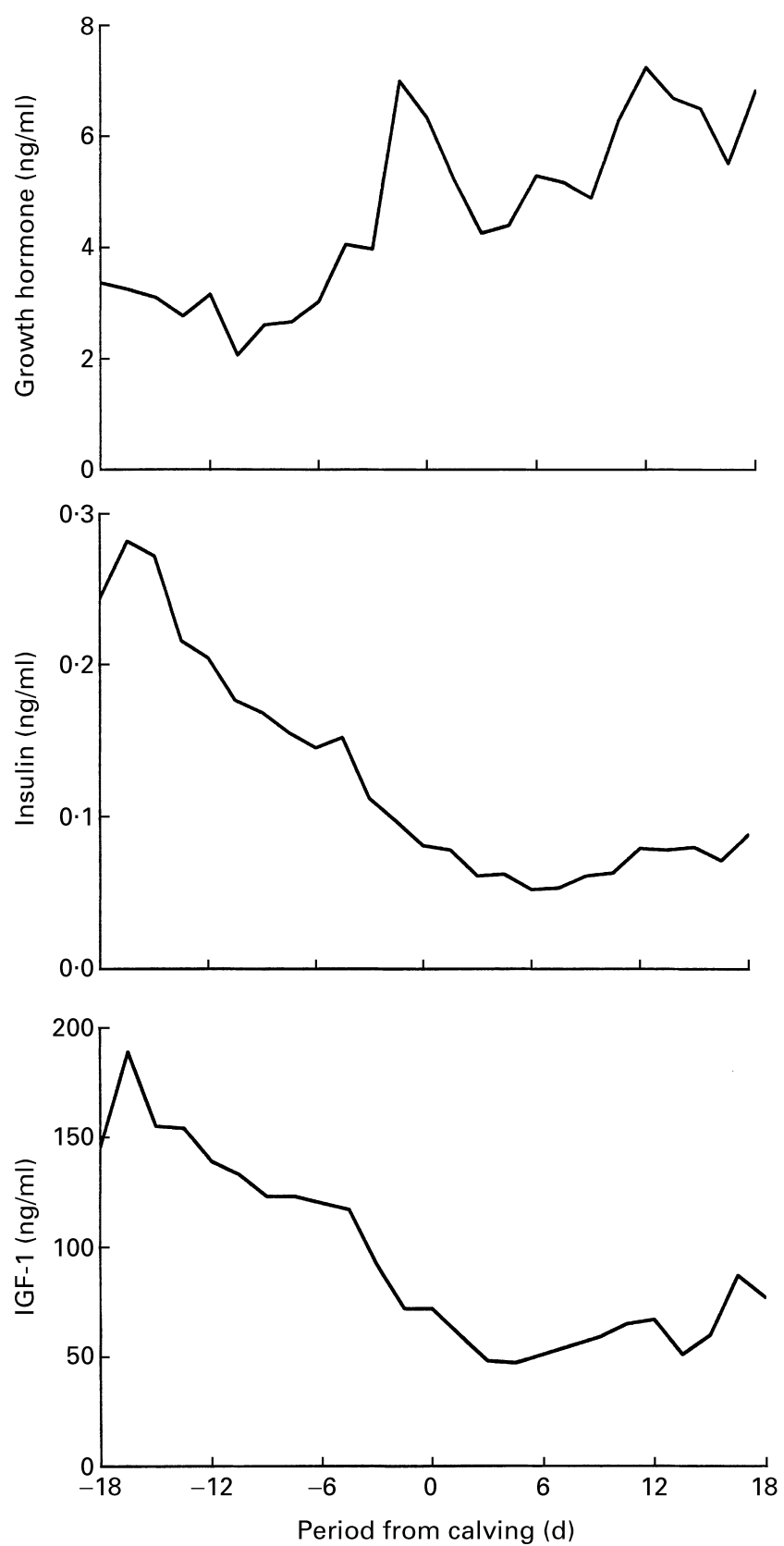

Fig. 4. Plasma concentrations of growth hormone, insulin, and insulin-like growth factor-I (IGF-I) in periparturient dairy cows ( $n 13)$. Cows were sampled by coccygeal venepuncture three times weekly before day -7 and after day 10 from parturition, and daily between days -7 and 10 from parturition.

is limited evidence that protein balance in maternal tissues can be improved by protein supplementation of pregnant ruminants, but it is unclear whether or when this might be of benefit during early lactation.

Finally, the regulatory mechanisms that permit the periparturient cow to simultaneously increase protein synthesis and accretion in splanchnic tissues and mobilize amino acids from peripheral tissues require detailed investigation. In addition to answering an intriguing academic question about regulation of nutrient partitioning, more fundamental 
understanding of these processes may explain some of the large individual variation among cows in their ability to stay healthy and highly productive after the transition from pregnancy to lactation.

\section{References}

Akers RM, Bauman DE, Capuco AV, Goodman GT \& Tucker HA (1981) Prolactin regulation of milk secretion and biochemical differentiation of mammary epithelial cells in periparturient cows. Endocrinology 109, 23-30.

Andrew SM, Waldo DR \& Erdman RA (1994) Direct analysis of body composition of dairy cows at three physiological stages. Journal of Dairy Science 77, 3022-3033.

Baracos VE, Brun-Bellut J \& Marie M (1991) Tissue protein synthesis in lactating and dry goats. British Journal of Nutrition 66, 451-465.

Bauchart D, Durand D, Gruffat D \& Chilliard Y (1998) Mechanisms of liver steatosis in early lactation cows - effects of hepatoprotector agents. Proceedings of the Cornell Nutrition Conference for Feed Manufacturers, pp. 27-37. Ithaca, NY: Cornell University.

Bell AW (1995) Regulation of organic nutrient metabolism during transition from late pregnancy to early lactation. Journal of Animal Science 73, 2804-2819.

Bell AW, Slepetis R \& Ehrhardt RA (1995) Growth and accretion of energy and protein in the gravid uterus during late pregnancy in Holstein cows. Journal of Dairy Science 78, 1954-1961.

Belyea RL, Frost GR, Martz FA, Clark JL \& Forkner LG (1977) Body composition of dairy cattle by potassium-40 liquid scintillation detection. Journal of Dairy Science 61, 206-211.

Bennink MR, Mellenberger RW, Frobish RA \& Bauman DE (1972) Glucose oxidation and entry rate as affected by the initiation of lactation. Journal of Dairy Science 55, 712 Abstr.

Burhans WS \& Bell AW (1998) Feeding the transition cow. Proceedings of the Cornell Nutrition Conference for Feed Manufacturers, pp. 247-258. Ithaca, NY: Cornell University.

Burhans WS, Briggs EA, Rathmacher JA \& Bell AW (1997) Glucogenic supplementation does not reduce body tissue protein degradation in periparturient dairy cows. Journal of Dairy Science 80, Suppl. 1, 166 Abstr.

Capuco AV, Akers RM \& Smith JJ (1997) Mammary growth in Holstein cows during the dry period: quantification of nucleic acids and histology. Journal of Dairy Science 80, 477-487.

Carson VM, Whitehouse NL, Kolinsky K, Garthwaite BD, Piepenbrink MS \& Schwab CG (1998) Interactions of prepartum and postpartum feeding of rumen inert amino acids on lactational performance. Journal of Dairy Science 81, Suppl. 1, 295 Abstr.

Chew BP, Murdock RR, Riley RE \& Hillers JK (1984) Influence of prepartum dietary crude protein on growth hormone, insulin, reproduction and lactation. Journal of Dairy Science 67, 270-275.

Chung M, Teng C, Timmerman M, Meschia G \& Battaglia FC (1998) Production and utilization of amino acids by ovine placenta in vivo. American Journal of Physiology 274, E13-E22.

Crawley DD \& Kilmer LH (1995) Effects of level and source of rumen degradable protein fed prepartum on postpartum performance of dairy cows. Journal of Dairy Science 78, Suppl. 1, 266 Abstr.

Debras E, Grizard J, Aina E, Tesseraud S, Champredon C \& Arnal M (1989) Insulin sensitivity and responsiveness during lactation and dry period in goats. American Journal of Physiology 256, E295-E302.

Durand D, Chilliard Y \& Bauchart D (1992) Effects of lysine and methionine on in vivo hepatic secretion of VLDL in the high yielding dairy cow. Journal of Dairy Science 75, Suppl. 1, 279 Abstr.

Gibb MJ, Ivings WE, Dhanoa MS \& Sutton JD (1992) Changes in body components of autumn-calving Holstein-Friesian cows over the first 29 weeks of lactation. Animal Production 55, 339-360.

Greenfield R, Donkin SS, Cecava MJ \& Johnson TR (1998) Protein requirements of transition dairy cows. Journal of Dairy Science 81, 1200 Abstr.

Greenhalgh JFD, Elsley FWH, Grubb DA, Lightfoot AL, Saul DW, Smith P, Walker D, Williams D \& Yeo ML (1977) Coordinated trials on the protein requirements of sows. I. A comparison of four levels of dietary protein in gestation and two in lactation. Animal Production 24, 307-321.

Gruffat D, Durand D, Chilliard Y, Williams P \& Bauchart D (1997) Hepatic gene expression of apolipoprotein B100 during early lactation in underfed, high producing dairy cows. Journal of Dairy Science 80, 657-666.

Gruffat D, Durand D, Graulet B \& Bauchart D (1996) Regulation of VLDL synthesis and secretion in the liver. Reproduction Nutrition Development 36, 375-389.

Grummer RR (1993) Etiology of lipid-related metabolic disorders in periparturient dairy cows. Journal of Dairy Science 76, 3882-3896.

Hippen AR, She P, Young JW, Beitz DC, Lindberg GL, Richardson LF \& Tucker RW (1999) Alleviation of fatty liver in dairy cows with 14-day intravenous infusions of glucagon. Journal of Dairy Science 82, 1139-1152.

Holtenius P \& Hjort M (1990) Studies on the pathogenesis of fatty liver in cows. Bovine Practitioner 25, 91-94.

Hook TE, Odde KG, Aguilar AA \& Olson JD (1989) Protein effects on fetal growth, colostrum and calf immunoglobulins and lactation in dairy heifers. Journal of Dairy Science 67, Suppl. 1, 539 Abstr.

Huyler MT, Dostal DF \& Kincaid RL (1997) The effect of level of undegradable intake protein in prepartum diets on postpartum performance of dairy cattle. Journal of Dairy Science 80, Suppl. 1, 259 Abstr.

Julien WE, Conrad HR \& Redman DR (1976) Influence of dietary protein on susceptibility to alert downer syndrome. Journal of Dairy Science 60, 210-215.

McGuire MA, Bauman DE, Dwyer DA \& Cohick WS (1995) Nutritional modulation of the somatotropin/insulin-like growth factor system: response to feed deprivation in lactating cows. Journal of Nutrition 125, 493-502.

McNeill DM, Slepetis R, Ehrhardt RA, Smith DM \& Bell AW (1997) Protein requirements of sheep in late pregnancy: partitioning of nitrogen between gravid uterus and maternal tissues. Journal of Animal Science 75, 809-816.

Mahan DC \& Mangan LT (1975) Evaluation of various protein sequences on the nutritional carry over from gestation to lactation with first litter sows. Journal of Nutrition 105, 1291-1298.

Mazur A, Ayrault-Jarrier M, Chilliard Y \& Rayssiguier Y (1992) Lipoprotein metabolism in fatty liver dairy cows. Diabetes and Metabolism 18, 145-149.

Minor DJ, Trower SL, Strang BD, Shaver RD \& Grummer RR (1998) Effects of nonfiber carbohydrate and niacin on periparturient metabolic status and lactation of dairy cows. Journal of Dairy Science 81, 189-200.

Moorby JM, Dewhurst RJ \& Marsden S (1996) Effect of increasing digestible undegraded protein supply to dairy cows in late gestation on the yield and composition of milk during the subsequent lactation. Animal Science 63, 201-213.

National Research Council (1989) Nutrient Requirements of Dairy Cattle, 6th revised ed. Washington, DC: National Academy Press. 
Overton TR, Drackley JK, Douglas GN, Emmert LS \& Clark JH (1998) Hepatic gluconeogenesis and whole-body protein metabolism of periparturient dairy cows as affected by source of energy and intake of the prepartum diet. Journal of Dairy Science 81, Suppl. 1, 295 Abstr.

Overton TR, Drackley JK, Otteman-Abbamonte CJ, Beaulieu AD, Emmert LS \& Clark JH (1999) Substrate utilization for hepatic gluconeogenesis is altered by increased glucose demand in ruminants. Journal of Animal Science 77, 1940-1951.

Pine AP, Jessop NS \& Oldham JD (1994) Maternal protein reserves and their influence on lactational performance in rats. British Journal of Nutrition 71, 13-27.

Putnam DE \& Varga GA (1998) Protein density and its influence on metabolite concentration and nitrogen retention by Holstein cows in late gestation. Journal of Dairy Science 81, $1608-1618$.

Putnam DE, Varga GA \& Dann HM (1999) Metabolic and production responses to dietary protein and exogenous somatotropin in late gestation dairy cows. Journal of Dairy Science 82, 982-995.

Reid IM, Roberts CJ \& Baird GD (1980) The effects of underfeeding during pregnancy and lactation on structure and chemistry of bovine liver and muscle. Journal of Agricultural Science, Cambridge 94, 239-245.

Rowlands GJ, Manston R, Pocock RM \& Dew SM (1975) Relationships between stage of lactation and pregnancy and blood composition in a herd of dairy cows and the influences of seasonal changes in management on these relationships. Journal of Dairy Research 42, 349-362.

Sahlu T, Hart SP, Le-Trong T, Jia Z, Dawson L, Gipson T \& The $\mathrm{TH}$ (1995) Influence of prepartum protein and energy concentrations for dairy goats during pregnancy and early lactation. Journal of Dairy Science 78, 378-387.

Segoale T, Perkins KH, Dwyer DA \& Bauman DE (1997) Changes in the insulin-like growth factor system with the onset of lactation. Journal of Dairy Science 80, Suppl. 1, 176 Abstr.

Shields RG, Mahan DC \& Maxson PF (1985) Effect of dietary gestation and lactation protein levels on reproductive performance and body composition of first litter female swine. Journal of Animal Science 60, 179-189.

Simmons CR, Bergen WG, Vandehaar MJ, Sprecher DJ, Sniffen CJ, Stanisiewski EP \& Tucker HA (1994) Protein and fat metabolism in cows given Somavubove before parturition. Journal of Dairy Science 77, 1835-1847.

Sniffen CJ, O'Connor JD, Van Soest PJ, Fox DG \& Russell JB (1992) A net carbohydrate and protein system for evaluating cattle diets: II. Carbohydrate and protein availability. Journal of Animal Science 70, 3562-3577.

Tyrrell HF \& Haaland GL (1983) A note on the body composition of dry, just calved, and mid-lactation Holstein cows. Journal of Dairy Science 66, Suppl. 1, 161 Abstr.

Van Saun RJ, Idleman SC \& Sniffen CJ (1993) Effect of undegradable protein amount fed prepartum on postpartum production in first lactation Holstein cows. Journal of Dairy Science 76, 236-244.

Van Saun RJ \& Sniffen CJ (1995) Effects of undegradable protein fed prepartum on lactation, reproduction, and health in dairy cattle. II. Postpartum diets and performance. Journal of Dairy Science 78, Suppl. 1, 265 Abstr.

Vernon RG, Faulkner A, Hay WW Jr, Calvert DT \& Flint DJ (1990) Insulin resistance of hind-limb tissues in vivo in lactating sheep. Biochemical Journal 270, 783-786.

Wheelhouse NM, Hazlerigg DG, MacRae JC \& Lomax MA (2000) The effect of methionine depletion on IGF-I secretion and protein synthetic rate in ovine hepatocytes. Proceedings of the Nutrition Society 59, OCA.

Wilson GF, Mackenzie DDS \& Brookes IM (1988) Importance of body tissues as sources of nutrients for milk synthesis in the cow, using ${ }^{13} \mathrm{C}$ as a marker. British Journal of Nutrition 60, 605-617. 